\title{
Evaluation of Elementary Science Teachers' Perceptions Regarding Inclusive Education Applications
}

\author{
Ş. Şenay İlik ${ }^{1} \&$ Esme Hacieminoglu ${ }^{2}$ \\ ${ }^{1}$ Necmettin Erbakan University, Ahmet Keleşoğlu Faculty of Education, Konya, Turkey \\ ${ }^{2}$ Akdeniz University, Faculty of Education, Antalya, Turkey \\ Correspondence: Ş. Şenay İlik, Necmettin Erbakan University, Ahmet Keleşoğlu Faculty of Education, Konya, Turkey.
}

Received: March 25, 2019 Accepted: April 28, 2019 Online Published: July 22, 2019

doi:10.11114/jets.v7i10.4396 URL:https://doi.org/10.11114/jets.v7i10.4396

\begin{abstract}
The purpose of this study is to investigate the problems and suggestions of the elementary science teachers having students with special needs in the inclusive education applications. The present study is a descriptive study which determines the opinions of elementary science teachers regarding inclusive education. Thirty seven in-service science teachers who have been working in schools where inclusive education is applied in different cities of Turkey participated in the study. Data were collected throughstructured interview form. Thirty-seven interview forms were completed with thirty-seven teachers working in the elementary schools. In an explicit coding process, the researchers grouped each data unit under a category according to common features. In the axial coding process, themes with characteristics similar to categories were classified and determined. When the themes emerged and in the selective coding process, the researchers tried to give meaning to these synthesized patterns. After the data was collected and analyzed, the following four main themes emerged: How do they deal with the inclusive student, the problems encountered in the classrooms where there are inclusive students, the methods applied, and the solutions suggested.
\end{abstract}

Keywords: inclusive education applications, elementary science teachers, Inclusive students

\section{Introduction}

Modern education aims to offer services in accordance with the needs of individuals and to plan the education considering individual differences. So, to integrate people with individual differences into society, it is of great significance to meet their educational needs by improving their physical, mental and social skills. As in all modern countries which improved their special education, our country strives to enable individuals with special needs to take advantage of rights and opportunities at the same level as typically developed children have. The primary effort is to make individuals with special needs to benefit from the least restrictive environment. The implementation of the least restrictive environment has been tried to be generalized over the last decade and it is accepted that the inclusion should be a priority in educational interventions (Diken \& Sucuoğlu, 1999).

Inclusion is defined as educating individuals with special needs in formal education environments by providing them with supportive educational services by their teachers in necessary circumstances (Diken \& Sucuoğlu, 1999). This education is provided to the students who show different developmental characteristics from their peers in terms of their individual characteristics in the same environment with their peers in accordance with their defined needs (Kuz, 2001; MEB, 2006). Another author defines inclusive education as special education practices that involve training the individuals with special educational needs along with their peers without deficiencies by providing them with support services at public and private pre-school, primary, secondary and non-formal education institutions (Osborne \& Dimattia, 1994).

It is frequently emphasized in recent students that inclusion should not be limited to students with special needs (Friend \& Bursuck, 2006; Wood, 2002). In other words, inclusion which is initially known as educating students with special needs in mainstream education is now considered to be provided to all students by taking their individual differences into consideration (Yazıcıoğlu \& Kargın, 2018). With inclusive education students with special needs and typically developed students contribute each other positively in academic and social fields by affecting each other. Besides, they gain many abilities which facilitate their adaptation to social life. 
The fact that chilren with special educational needs acquire social skills and gain independence depends on the successful implementation of the inclusive education programs (Orel, Töret \& Zerey, 2004). The success of inclusive education depends on the program implemented to students with special needs and typically developed students, their parents, the school staff, classroom teacher and other teachers. It is necessary for the teachers responsible for student's training, student with special needs, parents of the students with special needs, typically developed students and the other staff working in the school to work collaboratively for the success of the inclusive education (Kircaali-Ifftar \& Batu, 2007). Moreover, the physical condition of the school, the number of students in the class, supportive special education services, the type and duration of the inclusion, and the attitudes, experience and knowledge of the staff about inclusive education are the other factors which may affect the success of inclusive education (Diken \& Sucuoğlu, 1999).

The school staff, especially teachers, must make preliminary preparation regarding the children with special needs and inclusion implementations for the success of inclusive education. Teachers' making preparation is associated with their having undergraduate education or in-service training. This reveals the importance of training teachers who will work in the field of special education during their undergraduate education (Sar1 \& Saygin, 2002). Teachers' not having special education course largely affects the success of the education they provide. Another point which is as important as training teachers for inclusion is that the teachers should be willing to have inclusive students in their classes and they should have an approving attitude towards the inclusive students (Saraç \& Çolak, 2012).

When the literature examined, many studies which reveal the attitudes and opinions of teachers having inclusive students regarding inclusive education can be found (Uysal,1995; Giangreco, Edelman, Luiselli \& Macfarland, 1997; Sucuoğlu, 2004; Babaoğlan \& Yılmaz, 2010).

Uysal (1995) found that teachers had a positive attitude towards inclusive education and need more training and program adaptation training. Giangreco, Edalman, Luiselli and Macfarland (1997); Yılmaz (2013) suggested that before interacting with the students, teachers had negative attitudes towards inclusion but their attitudes changed positively after they interacted with the student. Janney, Snell, Beers and Raynes (1995) revealed that teachers found the inclusive education given in their school successful. They suggested that the problems should be overcome by a team in the school.

There are studies which found that the teachers have negative attitudes towards inclusion. Sucuoğlu (2004) found that more than half of the teachers thought that the inclusion was not beneficial. Moreover, they stated that physical conditions, knowledge, and abilities of the teachers were not enough for inclusive education. They also stated that legal regulations were not sufficient. They expressed that inclusive students were not evaluated properly and there were problems in their undergraduate education. Recent studies on inclusive education support these findings (Babaoğlan \& Yılmaz, 2010; Bilen, 2007; Demir \& Açar, 2010; Vural, 2008; Saraç \& Çolak, 2012)

There are studies which supports the negative opinions. Studies suggest that the teachers working in the mainstream education have negative attitudes towards inclusive education and these negative attitudes result from the insufficient knowledge (Diken, 1998; Avcıŏlu, Çetin \& Özbey, 2005). In other studies on inclusive education, it is found that the opinions of teachers changed positively when they get information and support training (Gözün \& Yıkmış, 2004; Sucuoğlu, Ünsal \& Özokçu, 2004). Diken (1998) compared the attitudes of teachers who have inclusive student and not towards inclusive education. Results revealed that quite a few teachers were willing to have inclusive students in their classes and the others were not willing to have inclusive students (Engin, Tosten, Kaya, \& Köselioğlu, 2014). Almost all the teachers participating in the study stated that they needed support training regarding inclusive education. Moreover, it was found that being experienced with students with special needs didn't affect the attitudes of teachers towards inclusive students.

In conclusion, in Tukey, there are some problems regarding the implementation of inclusive education. The most important one of these problems is that there isn't enough support service staff. Furthermore, there are other problems such as inappropriate physical conditions of school for inclusive education, insufficient knowledge of teachers and managers regarding inclusive education and negative attitudes of teachers towards inclusive education.(Batu, Kircaali-İftar \& Uzuner, 2004). When the studies on inclusive education are examined it can be seen that these studies mainly focus on special education teachers and teacher candidates, and classroom teachers and teacher candidates. There are few studies on science course which is one of the main courses of primary school. However, science course teaches not the knowledge they could use in the lesson they have but it also teaches solutions to problems they could encounter in real life (Ayvacı, Devecioglu \& Yiğit, 2002). Science education makes the students know and love the world and environment they live in. It enables them to effectively communicate with their teachers, friends and family. The language development of children can be improved more easily with the events they live and objects they interact. In order for the children to adapt to and be successful in real life, they should know science well and know how to take advantage of it (Hançer, Sensoy \& Yıldırım, 2003). This was conducted to contribute to the literature and to make 
suggestions to improve the quality of inclusive education. This study aims to investigate the opinions of the elementary school science teachers and to produce solutions.

In conclusion, the purpose of this study is to investigate the problems and suggestions of the elementary science teachers having students with special needs in the inclusive education applications. This qualitative study was carried out to answer the following specific question; What are the in-service science teachers' perceptions and practices regarding inclusive education applications.

\section{Method}

\subsection{Design of the Study}

The present study is a descriptive study which determines the opinions of elementary science teachers regarding inclusive education. Descriptive study is a research approach which aims to describe a past or present situation as it is (Karasar, 2009). Data were collected through structured interview form through e-mail. The main aim of the qualitative study is to deeply investigate the sample group (Yıldırım \& Şimşek, 2006).

\subsection{Study Group}

Thirty-seven in-service science teachers who have been working in schools where inclusive education is applied in different cities of Turkey participated in the study. The snowball sampling method and criterion sampling method were used in this study (Patton, 1990). The criterions for choosing the sample group were school type, years of teaching experience, location of the school and whether they took courses regarding inclusive education applications in undergraduate education. These criterias were informed to first participant selected as convenience sampling. Then the final structured interview form was send to the volunteer first participant via e-mail and s/he send to the participants providing criteria and the other participants send anothers they know. Structured interview form was completed by all volunteer participants and re-send through e-mail.The information about the in-service teachers' characteristics is summarized in Table 1.

Table 1. Characteristics of Participants

\begin{tabular}{|c|c|c|c|c|}
\hline $\begin{array}{l}\text { Teaching } \\
\text { experience }\end{array}$ & $\begin{array}{l}\text { School } \\
\text { Type }\end{array}$ & $\begin{array}{l}\text { Guidance } \\
\text { service }\end{array}$ & $\begin{array}{l}\text { Taking course regarding } \\
\text { inclusive education }\end{array}$ & Participant teacher \\
\hline \multirow[t]{8}{*}{$1-5$ years } & \multirow[t]{4}{*}{ Village } & \multirow[t]{2}{*}{ Exists } & Took a course & $10, \mathbf{1 1}, 12,13$ \\
\hline & & & Didn't take a course & 3, \\
\hline & & \multirow{2}{*}{$\begin{array}{l}\text { Does } \\
\text { exist }\end{array}$} & Took a course & 14 \\
\hline & & & Didn't take a course & $1,2,4$ \\
\hline & \multirow[t]{4}{*}{ City Center } & \multirow[t]{2}{*}{ Exists } & Took a course & $15,16,17,19,20,21,22,23$ \\
\hline & & & Didn't take a course & $5,7,8,9$ \\
\hline & & \multirow{2}{*}{$\begin{array}{l}\text { Does } \\
\text { exist }\end{array}$} & Took a course & 18 \\
\hline & & & Didn't take a course & 6 \\
\hline \multirow{8}{*}{$6-10$ years } & \multirow[t]{4}{*}{ Village } & \multirow[t]{2}{*}{ Exists } & Took a course & 28 \\
\hline & & & Didn't take a course & \\
\hline & & \multirow{2}{*}{$\begin{array}{l}\text { Does } \\
\text { exist }\end{array}$} & Took a course & 29 \\
\hline & & & Didn't take a course & 24 \\
\hline & \multirow[t]{4}{*}{ City Center } & \multirow[t]{2}{*}{ Exists } & Took a course & \\
\hline & & & Didn't take a course & 26 \\
\hline & & \multirow{2}{*}{$\begin{array}{l}\text { Does } \\
\text { exist }\end{array}$} & Took a course & \\
\hline & & & Didn't take a course & 25,27 \\
\hline \multirow[t]{8}{*}{ 10+years } & \multirow[t]{4}{*}{ Village } & \multirow[t]{2}{*}{ Exists } & Took a course & \\
\hline & & & Didn't take a course & \\
\hline & & \multirow{2}{*}{$\begin{array}{l}\text { Does } \\
\text { exist }\end{array}$} & Took a course & 36 \\
\hline & & & Didn't take a course & 30 \\
\hline & \multirow[t]{4}{*}{ City center } & \multirow[t]{2}{*}{ Exists } & Took a course & 37 \\
\hline & & & Didn't take a course & $31,32,33,34,35$ \\
\hline & & \multirow{2}{*}{$\begin{array}{l}\text { Does } \\
\text { exist }\end{array}$} & Took a course & \\
\hline & & & Didn't take a course & \\
\hline
\end{tabular}

\subsection{Data Collection Tool}

Data were collected through structured interview form. An interview form composed of 5 questions and developed by the researcher implemented to the participants. The interview form was examined by three experts who have experience in qualitative researches and necessary corrections were made in accordance with their opinions and feedbacks. The 
rearranged form was sent to the experts again to be examined. After the final opinions of the experts, the form took its final form. For the pilot study, the form was implemented to three teachers. After the pilot study, the form was re-sent to three experts experienced in qualitative studies to make the incomprehensible questions comprehensible. The final structured interview form was used as data collection tool.

\subsection{Data Analysis}

Patton (1990, p. 372) maintains that "there are no formulas for determining significance, there are no ways of perfectly replicating the researcher's analytical thought process, and there are no straightforward tests for reliability and validity". In an explicit coding process, the researchers grouped each data unit under a category according to common features. In the axial coding process, themes with characteristics similar to categories were classified and determined. When the themes emerged and in the selective coding process, the researchers tried to give meaning to these synthesized patterns (Hacieminoglu, 2014).

\section{Findings}

This section contains the analysis of questions asked to find out the opinions of elementary science teachers regarding the problems they have with the inclusive students. Thirty-seven interview forms were completed with thirty-seven teachers working in the elementary schools to investigate the problems and suggestions of the elementary science teachers having students with special needs in the inclusive education applications. After the data was collected and analyzed, the following four main themes emerged: How do they deal with the inclusive student, the problems encountered in the classrooms where there are inclusive students, the methods applied, and the solutions suggested.

\subsection{How Do the Teachers Deal with the Inclusive Students?}

When the answers of the participants regarding this question was examined, it was found out that 21 teachers stated that they didn't take a special education course in their undergraduate education, 2 teachers expressed that they took it as a topic in the counselling course and 1 teacher stated that he took the education with his own efforts. 16 teachers stated that they took a special education course in the undergraduate education. The opinions of some of the teachers are shown above.

"I didn't take any course about special education. Unfortunately, I am having difficulties now."

"I took a special education course in my undergraduate education but the course was theoretical. I met the inclusive students in the school for the first time. I think there should be some applications regarding inclusive education in our teaching practice course"

The answers of the teachers to the question "Do you deal with the inclusive students one to one?" are as follows: 19 teachers stated that they deal with the students one to one and 18 of them stated that they do not. While almost half of the teachers who stated that they deal with think that they cannot deal with enough, some teachers expressed that they deal with but the students have some motivation problems.

"I devote some time at the end of every lesson by taking into consideration the characteristics of the student. Mostly I take other students'time. But the student cannot be motivated; therefore, it is not efficient."

Teachers who tell they do not care for these students link this answer to different reasons. More than half of the teachers stated that their classrooms are too crowded to devote time to the students with special needs. Some of them expressed that they cannot deal with but they support them with homework. 4 teachers stated that these students have support education in support education room.

"Classrooms are too crowded and the differences among the typical students already make my job difficult. I couldn't find any time to devote inclusive students and I feel guilty about it. I give homework according to their level."

\subsection{The Problems Encountered In Classrooms with Inclusive Students}

Some of the teachers stated that they didn't have any problems in their classrooms. Some of the opinions of teachers are given below.

"The inclusive students in my class doesn't cause any problems. He can read and write faster than some of the typical students. So, I don't separate him from others and ...." (T13)

The problems encountered in classrooms with inclusive students can be classified into five categories. These are; compliance problems, problems encountered during the lesson, problems regarding in-class communication, and problems regarding the readiness level of inclusive students.

The first problem encountered by teachers in their classrooms is the compliance problem. Compliance problem emerges in two ways. First of them is the in-class compliance problem of inclusive student and secondly compliance problems with other students. Inclusive students are stated to have in-class compliance problems. Some of the opinions of 
teachers concerning in-class compliance problems are given below.

"I have some problems such as compliance to lesson, draw attention, and not maintaining the interest of other students for a long time." (T26)

"Generally, inclusive students have problems in the points of compliance to classroom environment and understanding lessons." (T20)

The other compliance problem emphasized by teachers is the compliance with other students. Some teachers stated that other students get uncomfortable when the level of the lesson gets lower and that their concentration is lost.

"Inclusive students change the flow of the lesson and distract other students'attention." (T1)

"It is hard to get on with these students. Sometimes fights break out among students. Moreover, it is hard for these students to understand the lesson. Some overachieving students can feel uncomfortable about this situation." (T7)

"inclusive students who have severe insufficiencies sometimes distract other students." (T9)

"Since he falls behind his classmates, he has problems. Typical students are affected negatively because my attention is mostly on the inclusive student."

Theme second theme of the problems encountered in classrooms with inclusive students is about classroom management. The reasons for the problems regarding classroom management are the physical insufficiencies of classrooms, noise, and irrelevant questions. The study suggests that the attention deficit, failure to exercise one on one teaching, negligence of others due to the obligation of completing the curriculum by deadlines and intervention of the lesson result from the class management problem.

"Because of the physical condition of the classroom, he has a problem of seeing my face. Besides, the class is very crowded and I cannot show the interest he requires." (T19)

"inclusive student is easily distracted, makes a lot of noise, speaks in the lesson, asks irrelevant questions and ruins the flow of the lesson." (T30)

"... It is hard to deal with the inclusive students and explain the lesson in a classroom with 40 students. I deal with him but I am totally insufficient." (T5)

The third theme is the problems encountered during the lesson. Regarding this theme, most science teachers stated that science lesson and its topics are not suitable for the level of the inclusive student. The second problem stated by teachers is the insufficient time and following the curriculum objectives in this insufficient time. The reasons for the problems encountered during the lesson are stated as having difficulties in taking their attention, limited activity variance, planning the lesson, and inclusive students' painting and drawing habits.

"I have had inclusive students experiencing literacy difficulties before. Those students were not engaged in courses as they were accustomed to drawing pictures and painting in the classroom. That was a great challenge. I couldn't keep them engaged in class because of their lower levels of academic performance. In addition, I was not able to interact actively with them due to over-crowded classrooms..." (T13)

"I cannot devote enough time to inclusive students in order to teach the subject in accordance with the curriculum within a class and not to distract other students' attention." (T31)

When I cannot interact with inclusive students personally, they may disturb peace and order in the classroom." (T7)

"In my opinion, inclusive students require extra attention from teachers. Time can be a challenge. Activities may be limited." (T6)

"Students experience difficulty adjusting to the class. They do not pay attention to the lectures as the subjects do not appeal to them." (T12)

The fourth theme is the problems related to communication in the classroom. There can also be consequences for communication problems in the classroom. Teachers have laid emphasis on the self-confidence problem encountered by inclusive students when it comes to problems caused by lack of communication. It is therefore clear that they become sociopaths and unwilling to take part in tasks. Besides, teachers have stated that they have observed other students in the class ridicule them, which has accordingly led to an increase in aggressive behavior and introvert manner inclusive students behaved.

"I am utterly opposed to the practice of inclusion. Our students would even become sociopaths, let alone socializing with other students. Their weaknesses are on the agenda on every occasion. It may, therefore, lead to deep wounds impossible to be treated for inclusive students. It is definitely hard to restore their damaged self-esteem. It is no wonder that I, as a teacher, have great difficulty..." (T5) 
Children feel bad about themselves as they are always ridiculed by other students. Thus, they become more introverted and aggressive." (T23)

The fifth theme related to the problems faced during the process is the readiness levels. Among the problems associated with readiness levels, the leading one is that inclusive students are illiterate, that is they do not know how to read and write. Though they sometimes know how to read and write, they experience a poor academic performance at school. It has been repeatedly claimed by teachers that they, therefore, have difficulty concentrating in class.

"My student is really quiet and not eager to have a talk and take part in schoolwork. I cannot get along well with him because he has a speech disorder..." (T2)

Methods used for solving the problems encountered in the education of inclusive students

Another subtheme of this study is the methods used for solving the problems encountered in the education of inclusive students. The ones used by teachers most are specified as assigning homework to inclusive students, communicating with parents and educational games. Other ones are "encouraging class participation, cooperation with guidance service, preparing questions and activities appropriate for their level, face-to-face teaching, paying special attention to them during the class and make them feel they are cared, giving them important responsibilities in the class, letting them sit in the front rows but not alone, getting opinions of experienced teachers and letting students work on simple activities. Some of the teachers who participated in this research also reported that they do not know any methods to solve the problems encountered in the classes involving inclusive students.

"It is necessary to take such students into consideration. Therefore, I create a seating chart where they are sitting in the front rows but alone. I give them responsibilities in school tasks so that they can get along well with other students. I also receive support from the guidance service." (T7)

It is essential that resource rooms appropriate to the level of inclusive students should be arranged. The practice having started this term is really effective. We keep in touch with the teacher working with my student all the time and newly acquired information has thereby started to become permanent for him/her. In addition, I have converted games played inside and outside the class into a science game. I have also incorporated inclusive students into this practice, thus asking them questions appropriate for their levels. As a result, not only what they have learned becomes permanent but their self-esteem rises as well." (T13)

"I have attempted to communicate with parents by means of guidance service but they have behaved totally indifferent..." (T15)

"I am working coordinately with the guidance service. The student is taking private lessons from the teachers having no duty during those hours. Otherwise, he/she lacks an academic background and has no chance to follow the class. But I do not think it is sufficient. He learnt almost nothing until the seventh grade. He/she needs more attention from now on. I am of the opinion that we cannot provide such assistance at school." (T19)

I make him feel that I pay special attention to him during the class. Using homework assignment, I am trying to make him feel like a typical student..." (T22)

"I have had a conversation with his classmates to tell them they should help him. I'm trying to implement the Individualized Education Program (IEP). I prefer face-to-face meetings with their parents." (T28)

"My pupil is sitting alone; I need to ignore some of his behaviors in order not to disrupt the flow of the lecture..." (T30)

Solution proposals for the challenges faced in the inclusive classroom

The common solution proposed by teachers is that resource rooms should be opened at schools. Besides, many teachers stated that special education classes should be opened at schools where inclusive students are taught. They laid emphasis on the principle that inclusive students should be provided with one-to-one teaching as in the resource rooms and special education classes. Another solution proposed is that they should be charged, set homework and given responsibilities in or outside the classroom.

"My proposal is that these students should be taught not in a general education class, but in another class in the same school arranged for them under the supervision of separate teachers or those who have received special training or in-service training." (T5)

"Challenges relating to time can be eliminated by allocating more or extra time outside the classroom to these students. Students can participate in self-study by discovering the way of learning themselves. Some students within the class can be selected as peer instructors so that they can help him/her." (T6)

"My proposal is that these students should receive certain courses together, whereas they should be given different courses they can easily understand in the other lessons." (T15) 
"For me, I do not believe that there will be a cohesion. On the contrary, inclusive students do not become socialized and the class is adversely affected by them. For instance, students with low academic performance want to be treated like them. That is to say, they want to be exempted from classes and homework assignments. They also ask for simple exams. Therefore, inclusive students should be taught in separate classes or schools." (T30)

"A resource room should be definitely arranged in each school. Students should take 'core courses' through one-to-one training in those classes. They should take skills-based courses such as visual arts, music and physical education together with typical ones. Children should have just fun instead of competing with their classmates." (T36)

\section{Discussion and Conclusions}

In the current study, when asked whether they have received training about special education, more than half of the science teachers said they have not received any training. A great majority of those stating they received training said they feel inadequate. This finding from the current study share similarities with some other studies conducted in the field (Kargin, Acarlar \& Sucuoğlu, 2004; Uysal, 1995; Symeonidou \& Phtiaka, 2009). In their study conducted in 2015, Dadandı\&UrfalıDadand 1 stated that a great majority of the teachers feel inadequate about inclusive students with specific learning difficulties. A review of the literature shows that other studies have obtained similar results as in our study (Diken, 1998; Eripek, 2004; Uysal, 1995).The results of this study show that the teachers have not received a comprehensive and adequate training related to inclusive education. It is also revealed that they are of the opinion that they have not taken advantage of support services. Other studies have revealed that classroom teachers working in inclusive classrooms did not receive support services. Accordingly, their lack of adequate preparation led to negative attitudes, which makes it difficult for the inclusive education program to be implemented successfully (Demir \& Acar, 2011). These results reveal that teachers need information about the educational and social activities students with special needs require.

In response to the question of whether they are teaching the inclusive students one-on-one, 19 of the teachers asserted they give individual care, while 18 of those said they do not give individual care. Nearly half of those teaching one-on-one say they pay close attention but do not think they are adequate, while some of them say they pay attention but the students experience motivation problems. The current study reveals that the most common challenge faced by teachers is that they have difficulty in making one-on-one contact. In the studies conducted by Vural (2008) andRakap\&Kaczmarak (2010) which support this study finding, the majority of classroom teachers taking part in inclusive education suggest that the allocated time is not adequate in relation to the challenges faced in the adaptation of teaching (Saraç \& Çolak, 2012). This finding of the research supports the results previously obtained in the studies in which the effectiveness of the applications related to the inclusive education (Saraç \& Çolak, 2012; Çuhadar, 2006; Vural \& Yıkmış, 2008).

When analyzing the findings based on the answers in response to the question "What kind of difficulties are you having in the classrooms with inclusive students?", some of the teachers interviewed indicated that they have no difficulty in the classrooms where inclusive students are educated. Based on the opinions of teachers having difficulty teaching, the problems faced by inclusive students in regular classrooms can be categorized into 5 sub-themes. These themes are; the challenges related to adjustment problems, the problems associated with classroom management, difficulties encountered during the teaching process, problems relating to communication in the classroom, and problems regarding the readiness levels of inclusive students.

The first theme of the challenges faced by teachers is that students experience various adjustment problems. Adjustment problems arise in two ways. The first one is they face difficulty adjusting to the class, while the second is communication problems with other students. Studies conducted so far have shown that inclusive students have difficulty in social interactions because of the challenges in their learning process compared to their peers and they are not accepted by them (Valas, 1999; Vaughn \& Elbaum, 1999), and they exhibit more maladaptive behaviors than their peers when experiencing peer rejection (Margalit, Tur-Kaspa \& Most, 1999). It is also suggested that these students tend to have fewer friendships compared to their peers and they lack the necessary skills to maintain interactions properly with peers (Vaughn \& Elbaum, 1999; Wiener \& Schneider, 2002). It is, therefore, thought that challenges related to classroom interaction that are included in teachers' expressions may be caused by inclusive students' lack of social skills. Compliance problems with others is one of the most-emphasized problems. It has also been suggested by the teachers involved in the study that another result about the compliance problem is that the other students feel disturbed and lose their concentration when the course level declines. It is clear from the teachers' statements that factors caused by both inclusive students and their classmates play a role in the problems emerged in the classroom.

The second theme is related to the problems regarding classroom management. The causes of the problems associated with classroom management have been identified as insufficient physical environment of the classrooms (e.g class being crowded), noise and asking irrelevant questions. In the study, attention deficit, not teaching one-on-one, not being 
able to deal with other students in order to keep up with the curriculum and division of the classroom are the results caused by the problems associated with classroom management. Professional experience of a teacher is considered as an important factor influencing his/her classroom management skills, and the methods teachers use in the classroom and their classroom management vary depending on the experience and expertise of them (Sucuoğlu, 2004). Studies conducted on the related issue indicate that student characteristics can influence classroom management and that teachers have difficulty in teaching these students with special needs and managing behavior problems (Sucuoğlu, 2004). Another study finding indicates that the level of classroom management knowledge of the teachers working in inclusive classrooms was limited. Several studies have shown that teachers working in inclusive classrooms are not adequately prepared to deal with problem behaviors emerging while teaching to the whole class (Sucuoğlu, 2004).

The third theme has been identified as "problems encountered during the teaching process". The problem related to this theme is that many teachers indicated that science course and its subjects are not suitable for the students' levels. It has been reported that duration problem and keeping up with the curriculum are the second most commonly encountered problem. The causes of having difficulty during the teaching process are 'having difficulty in capturing students' attention, limited range of activities, planning of the course, drawing and painting habits of inclusive students. In their study conducted with the inclusive students diagnosed as having a special learning disability, Dadand 1 \& Urfalı Dadand 1 (2015) suggested that students experience motivation problems towards the course according to the teachers. This point is thought to be related to the fact that most courses are arranged for the typically developed students and adequate learning time is not provided for inclusive students to grasp the subject easily. According to Demirdağ (2014), collaboration among teachers, using different teaching strategies, providing some basic modifications in materials and goals can improve their academic achievement, and accordingly their motivations for courses (Dadandı \& Urfalı Dadand1, 2015).

The fourth theme is the problems related to the communication in the classroom. Teachers laid emphasis on the self-esteem issue of the inclusive students as the problem caused by lack of communication. For this reason, it has been observed that they tend to become anti-social and not to participate in the course. In addition, teachers reported they have observed an increase in an aggressive manner and introvert manner inclusive students behaved when they are ridiculed by other students. In their study examining the effects of inclusion practices on students with special educational needs and their peers in a regular education class, Ruijs \& Peetsma (2009) concluded that inclusive students are excluded by other students and thus have difficulties in communication. Güleryüz (2009) conducted interviews with inclusive students. As a result of this study, it has been indicated that inclusive students have communication and adjustment issues. In his study investigating the competencies of primary school teachers in integration practices in contrast to other studies, Nizamoğlu (1996) found that inclusive students did not have any adjustment or communication problems with their peers and other students in the classroom accepted them.

The fifth theme encountered during the process is related to the readiness level. In the current study, the fact that inclusive students do not know how to read and write is among the major challenges associated with readiness levels. Though they sometimes know how to read and write, their performance within the class is poor. Therefore, it has been asserted by the teachers that they have difficulty in paying attention to the courses.

Another sub-question of the current study is the methods used by science teachers to solve the challenges they experienced in the classrooms with inclusive students. The most frequently used ones by the teachers among these methods are 'assigning homework to inclusive students', 'meeting with parents' and 'educational games'. Other ones are "encouraging class participation, cooperation with guidance service, preparing questions and activities appropriate for their level, face-to-face teaching, paying special attention to them during the class and make them feel they are cared, giving them important responsibilities in the class, letting them sit in the front rows but not alone, getting opinions of experienced teachers and letting students working on simple activities. Some teachers who participated in the study have reported that they do not know any methods to solve problems faced in the classrooms with inclusive students. An analysis of the regulations made by teachers during the teaching process shows that almost all teachers did not make any instructional arrangements. Some of them reported that they made the curriculum subjects simpler and let them participate in class by asking questions appropriate for students' level. There have been studies supporting the finding of the current study in the literature (Saraç \& Çolak, 2012). It was concluded in the study conducted by Bilen (2007) that the teachers who participated in the study did not prepare IEPs for the education of students with special needs and set instructional goals but they only made simple adjustments during the teaching process. In a study conducted by Vural (2008), it was concluded that though teachers stated they made simple adjustments in the preparation and presentation of the content, they tried to perform it in the implementation process without making preparations, leading to remain limited.

Teachers' recommendations to improve the qualification of inclusion have been examined, and their common proposed solution is that resource rooms should be opened at schools. Besides, many teachers indicated that special education 
classes should be opened at schools, where inclusive students are taught. Teachers emphasized that inclusive students should be offered face-to-face teaching as in the resource rooms and special education classes. Another solution proposed is that they should be charged, set homework and given responsibilities in or outside the classroom. When the results related to the "Recommendations' in the study conducted by Janney, Snell, Beers \& Raynes (1995) were examined, teachers suggested that better results can be achieved through teamwork in the education of inclusive students.

A large majority of teachers uttered that inclusive students need to be educated in a separate school as inclusive setting adversely affects these students. This issue is a rather controversial topic in the literature. There have been a number of studies supporting the finding of our current study, whereas some others showing its disadvantages are available (Batu, Kurcaali-İftar \& Uzuner, 2004). Studies have examined whether it will be better to educate children with special needs in regular education classrooms or special education classes. Those who suggest that children with special needs should be educated in special education classes emphasize it aims to protect children with special needs. It is therefore suggested that they do not want children with special needs to be disturbed or excluded by typically developing children Batu, Kurcaali-İftar \& Uzuner, 2004). Link (1991) recommends neither a completely separated educational setting for children with special needs nor a setting, where they are all educated together. According to Link, separated educational settings should be arranged; but necessary support services should be provided to those placed in a separate educational setting. Experts who suggest that students with special needs should be educated in regular education environments constitute a large majority (as cited in;Smith, Polloway, Patton \& Dowdy, 2002). It is suggested that students in the separate education environments are also isolated from their same-aged peers. Typically developing students taught alongside students with special needs in the regular education environments learn to communicate, interact, work together and share in the areas where they feel strong and weak (Batu, Kurcaali-İftarve Uzuner, 2004). Inclusive education should be given to not only elenmentary science teachers but also all branch teachers as compulsory courses in university education. In-service teachers who have not received inclusion education training should be given long-term in-service teacher training. Support education rooms should be used actively in schools. Families should educate their children to be respectful to each of their friends, respect their friends with differences and not act in a way to disturb emotionally.

\section{References}

Avcıŏlu, H., Eldeniz, Ç. M., \& Özbey, F. (2005). Sınıfında kaynaştırma öğrencisi bulunan sınıf ve brans öğretmenlerinin kaynaştırmaya yönelik tutumlarının incelenmesi. Özel eğitimden yansımalar, Ankara: KökYayıncılık, 79-89.

Ayvac1, H. Ş., Devecioğlu, Y., \& Yiğit, N. (2002). Okul öncesi öğretmenlerinin fen ve doğa etkinliklerindeki yeterliliklerinin belirlenmesi. V. Ulusal Fen Bilimleri ve Matematik Eğitimi Kongresi. Ankara.

Babaoğlan, E., \& Yılmaz, Ş. (2010). Competency of classroom teachers in the inclusive education. Kastamonu Education Journal, 2(18), 345-354.

Batu, S., Kırcaali-İftar, G., \& Uzuner, Y. (2004). Özel gereksinimli öğrencilerin kaynaştırıldığı bir kız meslek lisesindeki öğretmenlerin kaynaştırmaya ilişkin görüş ve önerileri. Ankara University Faculty of Educational Sciences Journal of Special Education, 5(2), 33-50.

Bilen, E. (2007). Primary school teacher's opinions about the problems they are facing during the integration activities and their solution proposals, Yayınlanmamışyükseklisanstezi, Dokuz Eylül Üniversitesi Eğitim Bilimleri Enstitüsü Sınıf Öğretmenliğ̣i Ana Bilim Dalı, İzmir.

Çuhadar, Y. (2006). Determining the views of the form masters and the principals concerning the preparation, implementation, monitoring and evaluation of the IEP for the students that are subject to coalescence education in classes 1-5 of elementary education, YayınlanmamışYüksekLisansTezi, Karaelmas Üniversitesi, Sosyal Bilimler Enstitüsü, Zonguldak.

Dadandı, İ., \& Urfal, D. P. (2015). Turkish teachers' opinions of the problems they face in the classroom of students with learning disabilities. Pegem Journal of Education and Instruction, 5(5), 509-532.

Demir, M. K., \& Açar, S. (2010). The Study of Classroom Teachers' Perspectives Towards Inclusive Education. Gazi University Journal of Gazi Educational Faculty, 30(3), 749-770.

Demir, M. K., \& Açar, S. (2011). Experienced classroom teachers' opinions on inclusive education, Kastamonu Education Journal, 3(19), 719-732.

Demirdağ, S. (2014). Effective teaching strategies and student engagement: Students with learning disabilities. International Journal of Teaching and Education, 2(3), 168-175. 
Diken, İ. H. (1998). A Comparing the attitudes of primary school teachers with and without mentally retarted children in their classrooms towards mainstreaming mentally retarded children, Yayınlanmamış YüksekLisans Tezi, Abant İzzet Baysal Üniversitesi, Sosyal Bilimler Enstitüsü, Bolu.

Diken, I. H., \& Sucuoğlu, B. (1999). Sınıfında zihin engelli çocuk bulunan ve bulunmayan sınıf öğretmenlerinin zihin engelli çocukların kaynaştıılmasına yönelik tutumlarının karşılaştırılması. Ankara University Faculty of Educational Sciences Journal of Special Education, 2(3), 25-39.

Engin, A. O., Tösten, R., Kaya, M. D., \& Köselioğlu, Y. S. (2014). The evaluation of manners and point of views related to mainstreaming education having responsibilities of students who are in needs of special education for primary education (Example of Kars). Kafkas University Journal of the Institute of Social Sciences, 13, 27-44.

Eripek, S. (2004). Türkiye'de zihin engelli çocukların kaynaştırılmasına ilişkin olarak yapılan araştırmaların gözden geçirilmesi. Ankara University Faculty of Educational Sciences Journal of Special Education, 5(2), 25-32.

Friend, M., \& Bursuck, W. D. (2006). Including students with special needs.a practical guide for classroom teachers. (4th Edition), Boston: Allyn\& Bacon Pearson Education Company.

Giangreco, M. F., Edelman, S. W., Luiselli, T. E., \& MacFarland, S. Z. (1997). Helping or hovering? Effects of instructional assistant proximity on students with disabilities. Exceptional Children, 64, 7-18.

Gözün, Ö., \& Yıkmış, A. (2004). Öğretmen adaylarının kaynaştırma konusunda bilgilendirilmelerinin kaynaştırmaya yönelik tutumlarının değişimindeki etkililiği. Ankara University Faculty of Educational Sciences Journal of Special Education, 5(2), 65-77.

Güleryüz, Ş. O. (2009). Kaynaştırma eğitimine devam eden engelli öğrencilerin akranları ile ilişkilerinde karşılaştıkları sorunların değerlendirilmesi. Yayınlanmamış yüksek lisans tezi, Selçuk Üniversitesi Eğitim Bilimleri Enstitüsü, Konya.

Hacieminoglu, E. (2014). How in-service science teachers integrate history and nature of science in elementary science courses. Educational Science: Theory \& Practices, 14(1), 353-372.

Hançer, H., Şensoy, Ö., \& Yıldırım, H. İ. (2003). An evalation about the importance of contemporary science education at elemantary schools and how this kind of science teaching must be. Pamukkale University Journal of Education, 13(1).

Janney, R. E., Snell, M. E., Beers, M. K., \& Raynes, M. (1995). Integrating students with moderate and severe disabilities into general education classes. Exceptional Children, 61(5).

Karasar, N. (2009). Bilimsel araştırma yöntemi: Kavramlar-ilkeler-teknikler. Nobel Yayın Dağitim

Kargın, T., Acarlar, F., \& Sucuoğlu, B. (2003). Öğretmen, yönetici ve anne-babaların kaynaştırma uygulamalarına ilişkin görüşlerinin belirlenmesi. Ankara Universitesi Egitim Bilimleri Fakultesi Ozel Egitim Dergisi, 4(2).

Kırcaali-İftar, G., \& Batu, S. (2007). Kaynaştırma, Ankara: KökYayıncılık.

Kuz, T. (2001). Kaynaştırma Eğitimine Yönelik Tutumların İncelenmesi. Ankara: T. C. Başbakanlık Özürlüler İdaresi Başkanlığı Yayınları.

Margalit, M., Tur-Kaspa, H., \& Most, T. (1999). Reciprocal nominations, reciprocal rejections and loneliness among students with learning disorders. An International Journal of Experimental Educational Psychology, 19(1), 79-90.

MEB (2018). Özel Ĕgitim Hizmetleri Yönetmeliği. Tebliğler Dergisi, 30471 .

Nizamoğlu, N. (1996). Sınıf öğretmenlerinin kaynaştırma uygulamalarındaki yeterlikleri. Yayınlanmamış Yüksek Lisans Tezi, Abant İzzet Baysal Üniversitesi, Sosyal Bilimler Enstitüsü, Bolu.

Orel, A., Töret. G., \& Zerey, Z. (2004). Sınıf öğretmeni adaylarının kaynaştırmaya yönelik tutumlarının incelenmesi. Ankara University Faculty of Educational Sciences Journal of Special Education, 5(1), 23-33.

Osborne, A. G., \& Dimittia, P. (1994). The least restrictive environment mandate: legal implications. Exceptional Children, 61(1), 6-14.

Patton, M. Q. (1990). Qualitative evaluation and research methods (2nd ed.). Newbury Park, CA: Sage.

Rakap, S., \& Kaczmarek, L. (2010). Teachers' attitudes towards inclusion in Turkey. European Journal of Special Needs Education, 25(1), 59-75.

Ruijs, N. M., \& Peetsma, T. T. D. (2009). Effects of inclusion on students with and without special educational needs reviewed. Educational Research Review, 4(2), 67-79.

Symeonidou, S., \& Phtiaka, H. (2009). Using teachers' prior knowledge, attitudes and beliefs to develop in-service 
teacher education courses for inclusion. Teaching and Teacher Education, 25(4), 543-550.

Saraç, T., \& Çolak, A. ( 2012). Elementary school teachers' views and suggestions regarding the problems encountered in the process of inclusive applications. Mersin University Journal of the Faculty of Education, 8(1), 13-28.

Sarı, H., \& Saygın, F. (2002).̈̈niversite öğrencilerinin özel eğitim dersi etkinlikleri almalarına yönelik ihtiyaçların analizi. XI. Ulusal Eğitim Kongresi Bildirileri. Konya: Eğitim Kitabevi Yayınları.

Smith, T. E. C., Polloway, E. A., Patton, J. R., \& Dowdy, C. A. (2002). Teaching children with special needs in inclusive settings (3rd ed.). Boston: Allyn\& Bacon.

Sucuoğlu, B. (2004). Türkiye'de kaynaştırma uygulamaları: Yayınlar/Araştırmalar (1980-2005), Ankara University Faculty of Educational Sciences Journal of Special Education, 5(2), 15-23.

Sucuoğlu, B., Ünsal, P., \& Özokçu, O. (2004). Kaynaştırma sınıfı öğretmenlerinin önleyici sınıf yönetimi becerilerinin incelenmesi. Ankara Üniversitesi Eğitim Bilimleri Fakültesi Özel Eğitim Dergisi, 5(2) 51-64.

Uysal, A. (1995). Öğretmen ve okul yöneteicilerinin zihin engelli çocukların kaynaştırllmasında karşılaşılan sorunlara iliş̧kin görüşleri .Andolu Üniversitesi Sosyal Bilimler Enstitüsü. Yayınlanmamış yüksek lisans tezi. Eskişehir.

Valas, H. (1999). Students with learning disabilities and low-achieving students: Peer acceptance, loneliness, self-esteem, and depression. Social Psychology of Education, 3(3), 173-192.

Vaughn, S., \& Elbaum, B. (1999). The self concept and friendships of students with learning disabilities: A developmental perspective. In R. Gallimore, L. P. Bernheimer, D. L. MacMillan, D. L. Speece, \& S. Vaughn (Eds), Developmental perspectives on children with high incidence disabilities., 81-107. Mahwah, NJ: Lawrence Erlbaum.

Vural, M., \& Yıkmış, A. (2008). A determination of the studies made on instructional adapdation by inclusive classroom teachers. Abant Izzet Baysal University Journal of Faculty of Education, 8(2), 141-159.

Vural, M. (2008). Kaynaştırma sınıfi öğretmenlerinin öğretimin uyarlanmasına iliş̧kin yaptıkları çalı̧̧maların belirlenmesi. Yayınlanmamış Yüksek Lisans Tezi. Abant İzzet Baysal Üniversitesi, Eğitim Bilimleri Enstitüsü, Bolu.

Wiener, J., \& Schneider, B. (2002). A multisource exploration of the friendship patterns of children with and without learning disabilities. Journal of Abnormal Psychology, 30, 127-141.

Wood, J. W. (2002). Adapting Instruction to Accommodate Students in Inclusive Settings. (4th Edition), Upper Saddle River, New Jersey: Merrill Prentice Hall.

Yazıcıoğlu, T., \& Kargın, T. (2018). Serebral palsili öğrenciler için düzenlenmiş bir okulda gerçekleştirilen kaynaştırma modeline ilişkin paydaş görüşleri. Ankara University Faculty of Educational Sciences Journal of Special Education, 19(4), 643-678.

Yıldırım, A., \& Şimşek, H. (2006). Sosyal bilimlerde nitel araştırma yöntemleri. Ankara: Seçkin Yayıncılık.

Yılmaz, A. (2013). According to teachers' view, assessment of defective students' education practice in the primary education school, Sosyal Politika Çalışmalarl, 31(13), 111-127.

\section{Copyrights}

Copyright for this article is retained by the author(s), with first publication rights granted to the journal.

This is an open-access article distributed under the terms and conditions of the Creative Commons Attribution license which permits unrestricted use, distribution, and reproduction in any medium, provided the original work is properly cited. 